\title{
Secretion of Insulinlike Growth Factor I and Insulinlike Growth Factor-binding Proteins by Murine Bone Marrow Stromal Cells
}

\author{
Sherry L. Abboud, * Christopher R. Bethel, ${ }^{*}$ and David C. Aron* \\ ${ }^{*}$ Department of Medicine, University of Texas Health Science Center, San Antonio, Texas 78284; and ${ }^{\ddagger}$ Division of Endocrinology and \\ Hypertension, Department of Medicine, Department of Veterans Affairs Medical Center,
} Case Western Reserve University School of Medicine, Cleveland, Ohio 44106

\begin{abstract}
Insulin-like growth factor I (IGF-I) stimulates hematopoiesis. We examined whether bone marrow stromal cells synthesize IGF-I. Secretion of IGF-I immunoreactivity by cells from TC-1 murine bone marrow stromal cells was time-dependent and inhibited by cycloheximide. Gel filtration chromatography under denaturing conditions of TC-1 conditioned medium demonstrated two major peaks of apparent IGF-I immunoreactivity with molecular weights of $\sim 7.5-8.0 \mathrm{kD}$, the size of native IGF-I, and > $25 \mathrm{kD}$. Expression of IGF-I mRNA was identified by both $\mathrm{RNase}$ protection assay and reverse transcription/ polymerase chain reaction. To determine whether the $>25-\mathrm{kD}$ species identified by RIA possessed IGF-binding activity, a potential cause of artifactual IGF-I immunoreactivity, charcoal adsorption assay of these gel filtration fractions was performed. The peak of IGF-binding activity coeluted with apparent IGF-I immunoreactivity suggesting that TC-1 cells secrete IGF-binding protein(s). Unfractionated conditioned medium exhibited linear dose-dependent increase in specific binding of ${ }^{125}$ I]-IGF-I with a pattern of displacement (IGF-I and IGF-II $\$$ insulin) characteristic of IGF-binding proteins. Western ligand analysis of conditioned medium showed three IGF-I binding species of $\sim 31,38$, and $40 \mathrm{kD}$. These data indicate that TC-1 bone marrow stromal cells synthesize and secrete IGF-I and IGF-binding proteins and constitute a useful model system to study their regulation and role in hematopoiesis. ( $J$. Clin. Invest. 1991. 88:470-475.) Key words: growth factor • growth factor binding proteins $\bullet$ bone marrow stroma
\end{abstract}

\section{Introduction}

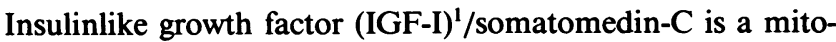
genic polypeptide structurally homologous with proinsulin (1). IGF-I, through its interaction with specific IGF-I receptors,

Portions of this work were presented in abstract form at the Annual Meeting of the American Society of Hematology, Boston, MA, December 1990 .

Address reprint requests to Sherry L. Abboud, M.D., Dept. of Medicine, University of Texas Health Science Center, 7703 Floyd Curl Dr., San Antonio, TX 78284.

Received for publication 6 February 1991 and in revised form 3 April 1991.

1. Abbreviations used in this paper: GM-CSF, granulocyte-macrophage colony stimulating factor; IGF, insulinlike growth factor; IGFBP, IGF binding protein.

J. Clin. Invest.

(c) The American Society for Clinical Investigation, Inc.

0021-9738/91/08/0470/06 \$2.00

Volume 88, August 1991, 470-475 mediates many of the growth-promoting effects of growth hormone (2). Although hepatic production of IGF-I appears to account for the majority of circulating IGF-I, it is also produced in a wide variety of extrahepatic tissues $(3,4)$. In addition, cells of mesenchymal origin such as fibroblasts $(5,6)$, smooth muscle cells (5), glomerular mesangial cells (7), and fat-storing cells of the liver (8) synthesize IGF-I in vitro. These cell types also possess IGF-I receptors (5-8). These findings suggest that IGF-I is not simply an endocrine hormone, but may also act through autocrine or paracrine mechanisms, having its biologic action at or near the site of origin $(9,10)$. The response of cells to IGF-I can be modulated by specific IGF binding proteins (IGFBP), which have been detected in plasma, body fluids, as well as in medium conditioned by several primary cell cultures and organ explants $(1,11-17)$. Regulation of hematopoiesis is a complex process that involves both multilineage and lineage-specific growth factors (18-20). IGF-I stimulates erythroid and granulocytic colony formation (2124). Recently, clonal culture techniques have demonstrated that the growth-promoting effects of growth hormone on erythroid and granulocytic progenitors is mediated indirectly in a paracrine fashion, via IGF-I $(22,23)$. Whereas IGF-I may be delivered by the serum, it is likely that IGF-I is synthesized within the marrow. However, the cells responsible for the production of IGF-I in the marrow microenvironment have not been precisely identified. Macrophages constitute a potential candidate, because the U937 macrophage cell line and alveolar macrophages, members of the monocyte-phagocyte system of bone marrow-derived cells, have been shown to synthesize IGF-I (25). In addition, T-lymphoblast cell lines also synthesize IGF-I (26). Bone marrow stromal cells play an important role in the regulation of hematopoiesis through direct cell-cell interaction and the release of cytokines $(26,27)$. Cultured murine TC-1 stromal cells, which elaborate several cytokines such as granulocyte-macrophage colony stimulating factor (GM-CSF), constitute a useful model system to study the production of other hematopoietic regulatory peptides such as IGF-I $(28,29)$. We have characterized IGF-I immunoreactivity in culture medium from TC-I cells and identified their expression of IGF-I mRNA. Our results indicate that TC-1 cells secrete both IGF-I and three IGFBP species of $\sim 31,38$, and $40 \mathrm{kD}$.

\section{Methods}

Stromal cell culture. The TC-1 stromal cells (kindly provided by Dr. P. Quesenberry, University of Virginia) are adherent cells isolated from murine long-term marrow culture. The TC-1-C11 cells also used are a subclone of TC-1. Their phenotypic characterization has been previously described (29). The stromal cell lines used in this study are known not to contain any retrovirus (29). The cells were maintained in Fischer's medium (Gibco Laboratories, Grand Island, NY), supplemented with $10 \mathrm{mM}$ Hepes, $2 \mathrm{mM}$ glutamine, $1 \mathrm{mM}$ sodium pyruvate, 
penicillin $100 \mathrm{U} / \mathrm{ml}$, streptomycin $100 \mu \mathrm{g} / \mathrm{ml}$, nystatin $25 \mathrm{ng} / \mathrm{ml}$, and $17 \%$ FCS (HyClone Laboratories, Inc., Logan, UT), and incubated at $37^{\circ} \mathrm{C}$ in $5 \% \mathrm{CO}_{2}$. Cells grown to confluence were passed weekly by exposure to $0.1 \%$ Trypsin (Gibco Laboratories). Cells from passages $35-42$ were used.

Cells were plated into 12-well dishes, allowed to reach confluence, washed twice with serum-free, insulin-free Fischer's medium and incubated overnight in the same medium. This medium was then discarded and fresh serum-free, insulin-free medium was added. Conditioned medium was collected after 8,24 , and $48 \mathrm{~h}$ and cell-free supernatants were stored at $-70^{\circ} \mathrm{C}$ for RIA. In some experiments, replicate wells of cells were incubated in the presence of cycloheximide at a final concentration of $10^{-5} \mathrm{M}$. Cells in each well were then trypsinized and counted using a Coulter counter (Coulter Electronics, Inc., Hialeah, FL).

Radioimmunoassay. The RIA utilized antiserum UBK487 (a gift from Dr. L. Underwood and Dr. J. J. Van Wyk, obtained from the Hormone Distribution Programs of the NIDDK). This antiserum has a $0.5 \%$ cross-reactivity with IGF-II and minimal cross-reactivity with insulin at $10^{-6} \mathrm{M}$. The assay was performed in polypropylene tubes using a protamine-containing phosphate buffer. Recombinant human IGF-I obtained from Collaborative Research, Inc. (Lexington, MA) was used as standard. Standard and unknowns (samples of unextracted culture medium or gel filtration column fractions) were incubated in duplicate with antibody (1:18,000 final dilution) for $2 \mathrm{~h}$ at room temperature before the addition of [ ${ }^{125}$ I] thr ${ }^{59}$-IGF-I ([ $\left.{ }^{125} \mathrm{I}\right]-$ IGF-I) (Amersham Co., Arlington Heights, IL). After overnight incubation, the antibody-bound [ ${ }^{125}$ I]-IGF-I was precipitated using goat antirabbit $\gamma$-globulin and normal rabbit serum as a carrier $(7,8)$.

Gel filtration chromatography. Culture medium $(80 \mathrm{ml})$ prepared as above and conditioned for $24 \mathrm{~h}$ by six $75-\mathrm{cm}^{2}$ flasks was pooled and concentrated by passage over $500 \mathrm{mg}$ octadecylsilane silica column ( 7 , $8,11)$. The retained moieties were then eluted with $90 \%$ acetonitrile in $0.1 \%$ aqueous trifluoroacetic acid and concentrated by a Speed-Vac concentrator (Savant Instruments, Inc., Farmingdale, NY). The dried residues were dissolved in $6 \mathrm{M}$ guanidine- $\mathrm{HCl}$ and applied to a 0.7 $\times 45-\mathrm{cm}$ Sephadex G-100 column equilibrated in $6 \mathrm{M}$ guanidine $\mathrm{HCl} /$ $0.03 \%$ Brij. The column was calibrated with a series of standards, including blue dextran, cytochrome $c$ (mol wt $12.4 \mathrm{kD}$ ), and [ $\left.{ }^{125} \mathrm{I}\right]-\mathrm{IGF}-\mathrm{I}$. Recovery of the applied radioactivity was $>90 \%$. Fractions were assayed for IGF-I immunoreactivity.

RNase protection assay for IGF-I mRNA. RNA from confluent TC-1 and TC-1-C-11 cells was extracted with guanidinium isothiocyanate, isolated by centrifugation through cesium chloride extracted with phenol/chloroform, precipitated with ethanol, and stored in water at $-70^{\circ} \mathrm{C}(30,31)$. Poly $(\mathrm{A})^{+}$was prepared by oligo $(d T)$-cellulose affinity chromatography $(30,31)$. Mouse and rat liver poly $(\mathrm{A})^{+} \mathrm{RNA}$ was obtained from Clontech Laboratories, Inc. (Palo Alto, CA). The nucleotide probe consisted of a 956-bp genomic fragment encompassing exon 3 and portions of the adjacent introns of the rat IGF-I gene that had been subcloned into pGEM2 (a gift from Dr. P. Rotwein, Washington University, St. Louis, MO) (32). A ${ }^{32}$ P-labeled single-stranded RNA probe was synthesized in an antisense orientation. Probe synthesis was initiated by T7 RNA polymerase in the presence of $40 \mathrm{mM}$ dithiothreitol/RNasin (40 U/ml) (Promega Corp., Madison, WI)/0.5 $\mathrm{mM}$ each ATP, GTP, and CTP/12 $\mu \mathrm{M}$ UTP $/ 50 \mu \mathrm{Ci}$ of $\left[{ }^{32} \mathrm{P}\right] \mathrm{UTP}(800$ $\mathrm{Ci} / \mathrm{mmol} / / 10 \mu \mathrm{g}$ of linearized template DNA as digested by DNase I, and the reaction mixture was extracted and precipitated. This synthesized RNA probe $\left(1 \times 10^{6} \mathrm{cpm}\right)$ was hybridized to TC-1 poly(A) ${ }^{+}$ RNA in $80 \%$ formamide/ $10 \mathrm{mM}$ Pipes $/ 400 \mathrm{mM} \mathrm{NaCl} / 1 \mathrm{mM}$ EDTA for $12 \mathrm{~h}$ at $50^{\circ} \mathrm{C}$. After hybridization, the reaction mixture was digested sequentially with RNases $A(50 \mu \mathrm{g} / \mathrm{ml})$ and $\mathrm{T} 1(2 \mu \mathrm{g} / \mathrm{ml})$ and then proteinase $\mathrm{K}(0.16 \mathrm{mg} / \mathrm{ml})$. The products were analyzed by electrophoresis through a $7 \mathrm{M}$ urea/6\% acrylamide gel, followed by autoradiography (33).

Reverse transcription PCR analysis of IGF-I mRNA. RNA was reverse transcribed using an anti-sense primer from IGF-I exon $3\left(5^{\prime}\right.$ CTTCTGAGTCTTGGGCATGTCAGT- $3^{\prime}$ ). After the addition of sense primer from IGF-I exon 2 (5'-GACCCTTTGCGGGGCT-
GAGCTGGT- $3^{\prime}$ ) the sample was heated at $94^{\circ} \mathrm{C}$ for $5 \mathrm{~min}$. Amplification of cDNA was carried out with the Perkin Elmer Cetus Gene Amp kit (Norwalk, CT) according to the specifications of the manufacturer in a M. J. Research, Inc. thermal cycler (Watertown, MA) (19). The first six cycles involved denaturation at $94^{\circ} \mathrm{C}$ for $1 \mathrm{~min}$, primer annealing at $55^{\circ} \mathrm{C}$ for $1.5 \mathrm{~min}$, and extension at $72^{\circ} \mathrm{C}$ for $2 \mathrm{~min}$. Further amplification was performed for 26 additional cycles, each cycle involving denaturation at $94^{\circ} \mathrm{C}$ for $1 \mathrm{~min}$, primer annealing at $60^{\circ} \mathrm{C}$ for $1.5 \mathrm{~min}$, and extension at $72^{\circ} \mathrm{C}$ for $2.5 \mathrm{~min}$. After a total of $32 \mathrm{cycles}$, the reaction product was subjected to gel electrophoresis on $2 \%$ agarose and stained with ethidium bromide $(30,31)$. The predicted amplified DNA is a 250-bp fragment.

Charcoal adsorption assay for IGF-binding activity. IGF binding activity was measured using a modification of Martin and Baxter (8, 34). Triplicate aliquots of conditioned media were incubated with [25I]-IGF-I in $500 \mu$ l of $50 \mathrm{mM}$ Tris- $\mathrm{HCl}, 0.1 \%$ BSA (Sigma Chemical Co., St. Louis, MO), $\mathrm{pH}$ 7.4. After $2 \mathrm{~h}$ incubation at room temperature, $1 \%$ activated charcoal (Sigma Chemical Co.) without protamine was added to the samples followed by incubation for $15 \mathrm{~min}$ and centrifugation at $4^{\circ} \mathrm{C}$. Aliquots of supernatant containing protein bound $\left[{ }^{125} \mathrm{I}\right]-$ IGF-I were counted. Nonconditioned medium was assayed in parallel and was subtracted from total bound radioactivity to determine specific binding activity. Displacement curves were generated by coincubation with dilutions of unlabeled human IGF-I and rat IGF-II (multiplication stimulating activity), obtained from Collaborative Research Inc. (Lexington, MA), or bovine insulin (Sigma Chemical Co.). Aliquots of selected fractions from the gel filtration column were assayed in duplicate. The final concentration of guanidine- $\mathrm{HCl}$ was $0.06 \mathrm{M}$. Equal amounts of gel filtration column buffer were assayed in parallel and subtracted from total bound radioactivity to determine specific binding.

Western Blot analysis of IGF-binding proteins. Samples of conditioned medium from TC-1 murine bone marrow stromal cells and from Buffalo rat liver cells (kindly provided by Dr. N. Ross, University of California, Los Angeles) were electrophoresed through a 10\% SDSpolyacrylamide gel. Separated proteins were electroblotted onto nitrocellulose filters and then incubated with [ $\left.{ }^{125} \mathrm{I}\right]-\mathrm{IGF}-\mathrm{I}$ overnight at $4^{\circ} \mathrm{C}$ and visualized by autoradiography by the method of Hossenlopp $(8,35)$.

\section{Results}

Serial dilutions of culture medium (5-200 $\mu \mathrm{l})$ caused dose-dependent inhibition of [ ${ }^{125}$ I] - IGF-I binding to anti-IGF-I serum, with a pattern of inhibition similar to that observed with synthetic IGF-I (Fig. 1). To exclude the possibility that IGF-I immunoreactivity in the conditioned medium represented carryover from the serum-containing medium, a time-course of the appearance of IGF-I immunoreactivity in serum-free, insulinfree medium conditioned by TC- 1 cells was examined in the absence and presence of cycloheximide. In the absence of cycloheximide, IGF-I immunoreactivity (mean \pm SE) was 180 (mean of two experiments), $370 \pm 151$, and $479 \pm 169 \mathrm{pg} / 10^{5}$ cells at 8,24 , and $48 \mathrm{~h}$, respectively. Addition to the cultures of cycloheximide $\left(10^{-5} \mathrm{M}\right.$, a concentration which did not affect cell viability as assessed by cell count and Trypan blue exclusion) resulted in a marked decrease (to less than the assay detection limit) in IGF-I immunoreactivity at each time point as compared with control wells, indicating that the presence of IGF-I immunoreactivity in the media is likely due to de novo protein synthesis.

Because IGFBPs in unextracted culture medium may alter apparent IGF-I immunoreactivity, we separated IGF-I from its binding proteins by denaturing gel filtration chromatography and characterized the size distribution of the secreted IGF-I 


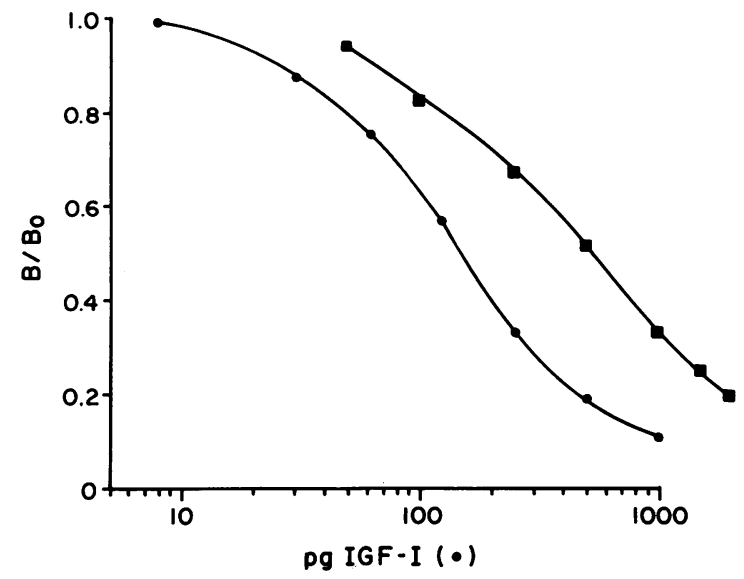

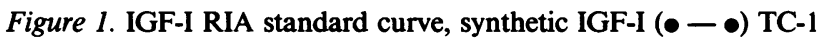
murine bone marrow stromal cell conditioned medium $(24 \mathrm{~h})$ ( - - ). $B / B_{0}: B_{0}=$ binding in the absence of added unlabeled peptide. $B$, binding in the presence of unlabeled peptide.

immunoreactive species. Serum-free, insulin-free culture medium conditioned by TC-1 cells was concentrated by reversephase chromatography and applied to a Sephadex G-100 column equilibrated in $6 \mathrm{M}$ guanidine-HCl/0.03\% Brij, a denaturing buffer. The gel filtration elution profile of IGF-I immunoreactivity is shown in Fig. 2. The gel filtration fractions demonstrated two major peaks of apparent IGF-I immunoreactivity. One peak coeluted with [ $\left.{ }^{125} \mathrm{I}\right]-\mathrm{IGF}-\mathrm{I}$ indicating a molecular weight of $\sim 7.5-8.0 \mathrm{kD}$, the size of native IGF-I. The second peak had an apparent molecular weight $>25 \mathrm{kD}$.

To characterize further the nature of the IGF-I immunoreactivity in TC-1 cells, we examined the expression of IGF-I mRNA with RNase protection assay using a complementary RNA probe derived from a genomic subclone of rat IGF-I con-

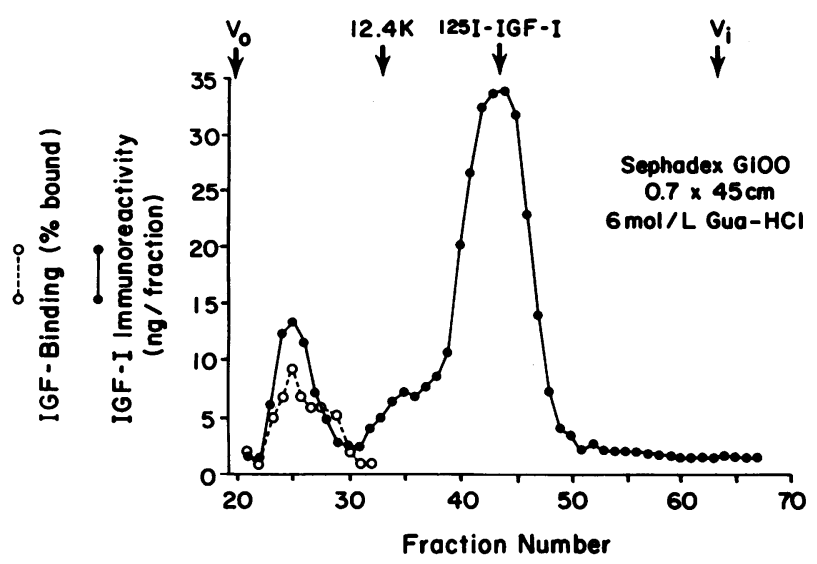

Figure 2. Sephadex G-100 gel filtration elution profile (6 M guanidine- $\mathrm{HCl} / 0.03 \%$ Brij) of conditioned medium $(24 \mathrm{~h})$ concentrated by reverse phase chromatography from TC-1 murine bone marrow stromal cells. The elution position of molecular weight markers are indicated by the arrows. $V_{0}$, void volume (blue dextran); $12.4 \mathrm{~K} ; V_{\mathrm{i}},{ }^{125} \mathrm{I}$ volume. Column fractions were assayed for IGF-I immunoreactivity by RIA; two major species with apparent IGF-I immunoreactivity are observed. The smaller species coelutes with [ $\left.{ }^{125} \mathrm{I}\right]-\mathrm{IGF}-\mathrm{I}$. High-molecular weight fractions were assayed for IGF-binding activity by charcoal adsorption assay; the peak of IGF-binding activity coeluted with the peak of apparent IGF-I immunoreactivity. taining exon 3. The autoradiogram shown in Fig. 3 shows the predicted 182-bp fragment protected from ribonuclease digestion in lanes with aliquots of poly $(A)^{+}$RNA isolated from TC- 1 and the TC-1-C-11 subclone of marrow stromal cells. Similar results were observed with both mouse and rat liver poly(A) ${ }^{+}$ RNA. No such species was observed with tRNA or probe alone. Because this method used a rat probe and because there are 10-bp differences between rat and mouse in this 182-bp exon, it appears that the RNase protection assay does not possess $100 \%$ specificity. Therefore, oligonucleotide primers based on the sequence of exons 2 and 3 of mouse IGF-I mRNA were used to perform reverse transcription and polymerase chain reaction. Ethidium bromide staining of the amplified products subjected to electrophoresis, is shown in Fig. 4. The predicted 250-bp fragment is observed; contamination of the initial sample with genomic DNA would result in an amplified fragment much larger in size.

Because the presence of IGFBPs might contribute to an apparent (albeit artifactual) increase in IGF-I immunoreactivity in the double-antibody RIA, we examined whether the higher molecular weight species identified by RIA of the gel filtration fractions possessed IGF-binding activity as determined by the charcoal adsorption assay. The peak of IGF-binding activity in these high molecular weight fractions coeluted

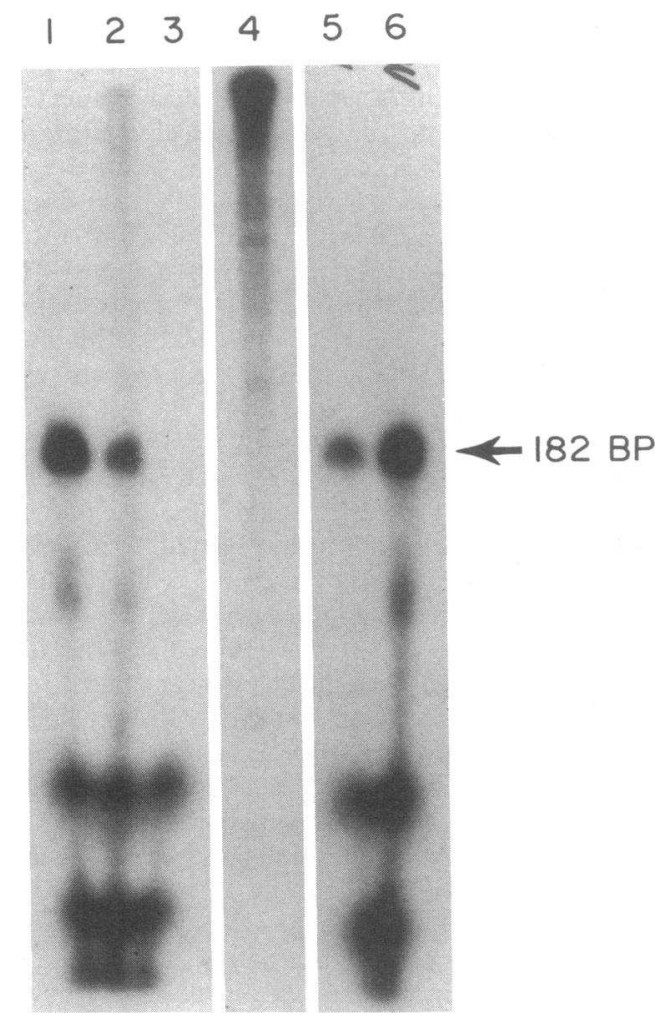

Figure 3. RNase protection assay for IGF-I mRNA in TC-1 and TC1-C-11 murine bone marrow stromal cells. A ${ }^{32}$ P-labeled single-standard complementary RNA probe derived from a genomic subclone of rat IGF-I containing exon 3 was hybridized with $10 \mu \mathrm{g}$ of poly(A) ${ }^{+}$RNA from confluent TC-1 (lane 1) and TC-1-C-11 (lane 2) cells. $0.5 \mu \mathrm{g}$ of poly $(\mathrm{A})^{+} \mathrm{RNA}$ from normal rat (lane 5) and mouse (lane 6) liver were used as controls. Autoradiogram shows the predicted 182bp fragment protected from ribonuclease digestion. After hybridization to tRNA, the probe was completely digested by RNase (lane 3). Lane 4 shows probe alone. 


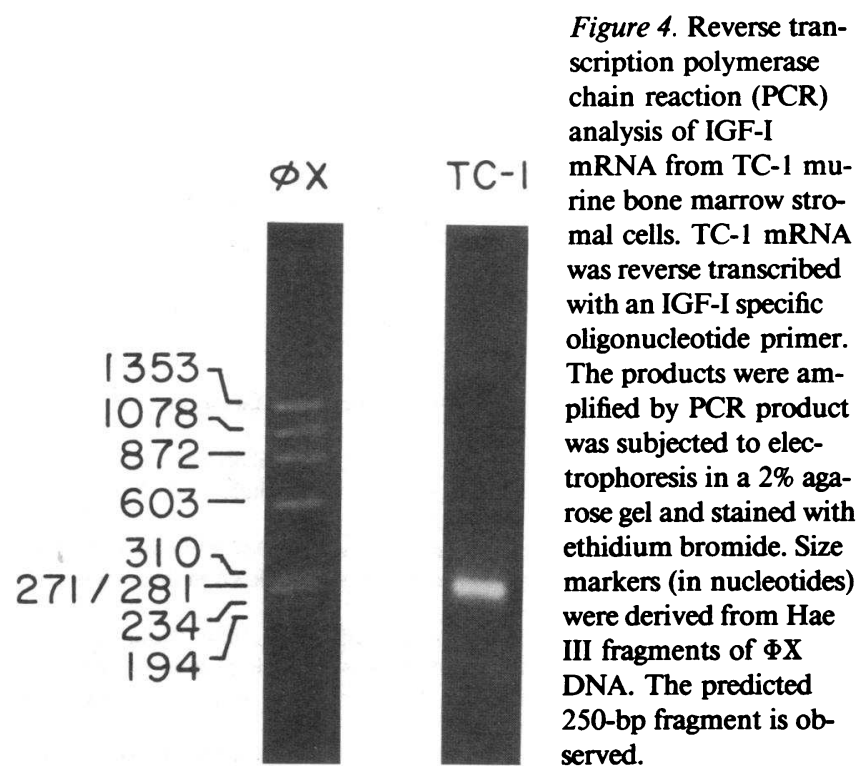

with the peak of apparent IGF-I immunoreactivity (Fig. 2), suggesting that TC-1 cells secrete IGF-binding protein(s). Because high molecular weight fractions derived from conditioned medium concentrated by octadecylsilane silica reverse chromatography, a method associated with low recovery of IGFBPS (11), showed IGF-binding activity, we then analyzed by charcoal absorption assay samples of culture medium conditioned by TC-1 cells. Serial dilutions of conditioned medium ranging from 2 to $50 \mu \mathrm{l}$ resulted in a linear dose-dependent increase in specific binding of $\left[{ }^{125} \mathrm{I}\right]-\mathrm{IGF}-\mathrm{I}$ (data not shown). The competitive binding characteristics of TC-1 conditioned medium are shown in Fig. 5. Displacement of [ $\left.{ }^{125} \mathrm{I}\right]$-IGF-I binding by rat IGF-II was somewhat greater than that by human IGF-I. There was no displacement by bovine insulin. This pattern of displacement is characteristic of IGFBPs. To character-

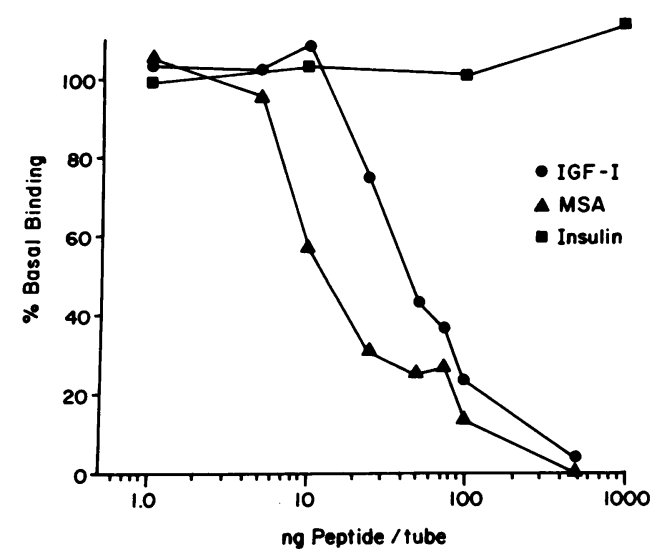

Figure 5. Competition curves for [ ${ }^{125}$ I]-IGF-I binding displacement by human IGF-I, rat IGF-II (MSA), and insulin. Serum-free, insulin-free medium conditioned by TC-1 murine bone marrow stromal cells was harvested as stated in Methods. IGF binding activity was assessed by the charcoal adsorption assay. Samples were incubated with serial dilutions of IGF-I, IGF-II, or insulin. Results are expressed as percentage of basal binding. Each point in this representative experiment represents the mean of triplicate determinations. Basal binding was $33 \%$ of added counts.

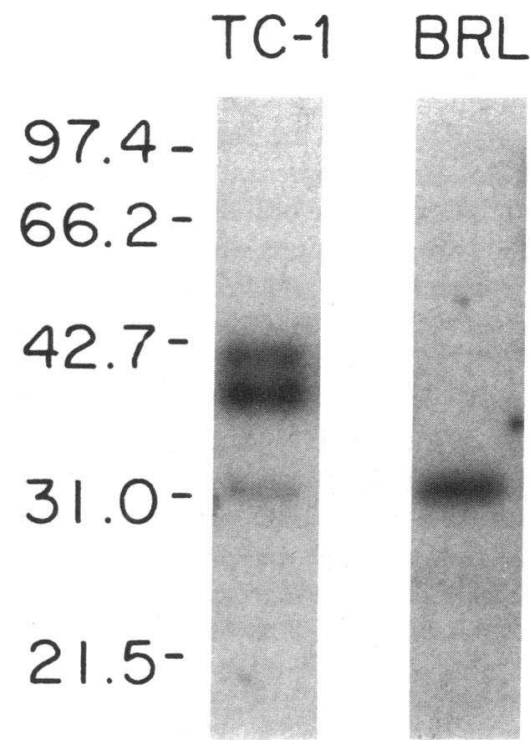

Figure 6. Western ligand analysis of IGF binding proteins in TC1 murine bone marrow stromal cell conditioned medium (48 h). Samples of culture medium conditioned by TC-1 cells $(15 \mu \mathrm{l})$ or Buffalo rat liver cells $(1 \mu \mathrm{l})$ were subjected to electrophoresis through an SDS-polyacrylamide gel (10\%). Separated proteins were electroblotted onto nitrocellulose filters and then incubated with [ ${ }^{125}$ I]-IGF-I overnight at $4^{\circ} \mathrm{C}$ and visualized by autoradiography. Molecular weights in kilodaltons were determined by comparison to a series of standards. Species of 31,38 , and $40 \mathrm{kD}$ were observed in conditioned medium from TC-1 cells (lane 1 ) and $31 \mathrm{kD}$ in conditioned medium from Buffalo rat liver cells (lane 2).

ize the size distribution of IGF-binding species in conditioned medium Western ligand analysis was performed. As shown in Fig. 6, three IGF-I binding species of $\sim 31,38$, and $40 \mathrm{kD}$ were observed, whereas a single species of $31 \mathrm{kD}$ was observed with conditioned medium from Buffalo rat liver cells, a source of IGFBP-2.

\section{Discussion}

IGF-I or somatomedin C is a biologically active growth factor with a wide variety of actions including stimulation of hematopoiesis $(2-24,36,37)$. The liver is the major source of circulating IGF-I. However, many of IGF-I's actions are paracrine in nature and depend upon local synthesis of IGF-I. Recent studies have demonstrated that a variety of mesenchymal cells synthesize or secrete IGF-I-like peptides and IGFBPs. Our data indicate that TC-1 marrow stromal cells synthesize and secrete IGF-I and IGFBPs. Of the two species containing IGF-I immunoreactivity found in culture medium from these cells, one had an apparent molecular weight of $7.5 \mathrm{kD}$, the same size as native IGF-I, suggesting that this species is indeed IGF-I. The identification of specific IGF-I mRNA by RNase protection assay and reverse transcription polymerase chain reaction support the identification of the $7.5-\mathrm{kD}$ immunoreactive IGF-I species as authentic IGF-I (38).

In addition to the 7.5-kD IGF-I species detected in TC-1 conditioned medium on gel filtration chromatography, a highmolecular weight species $(>25 \mathrm{kD}$ ) containing apparent IGF-I immunoreactivity was found. It is possible that this highermolecular weight species represents an IGF-I precursor which can be processed by proteolytic cleavage to yield IGF-I $(1,39)$. High-molecular weight forms of IGF-I have been observed in culture medium conditioned by human fibroblasts (6), macrophages (25), and Sertoli cells (40). However, the fact that the denaturing buffer (6 M guanidine $\mathrm{HCl}$ ) used in the gel chro- 
matographic fractionation procedure dissociates IGF-I from its binding proteins and that the presence of IGF-binding species might result in an artificially high level of IGF-I immunoreactivity in the double antibody RIA raised the possibility that the high-molecular weight species might represent an artifact due to the presence of IGFBPs. The presence of IGF-binding activity in these high-molecular weight fractions was confirmed by charcoal adsorption assay. Moreover, unfractionated conditioned medium exhibited IGF-binding activity with a pattern of affinity (IGF-I and IGF-II $\gg$ insulin) characteristic of IGFBPs. Western ligand analysis of TC- 1 conditioned medium demonstrated the presence of three IGF binding species of 31 , 38 , and $40 \mathrm{kD}$. The 1:4 ratio of IGFBP to the $7.5 \mathrm{kD}$ IGF-I immunoreactive species in conditioned medium based upon denaturing gel filtration chromatography is an underestimate due to the low recovery of IGFBPs from reverse phase chromatography (10). The coelaboration of IGF-I and IGFBP by TC-1 cells has been observed with other cell types $(7,8,41,42)$. Three major IGFBPs have been described-BP1, BP2, and BP3-in both the human and rat $(12,13)$. The 150-kD IGFBP complex in serum dissociates into IGF, an acid-labile component without affinity for IGFs, and a 53-kD IGFBP, a glycosylated form of BP3. Recently, additional IGFBPs have been identified $(43,44)$. The physiological importance of IGFBPs remains to be clarified. Specific binding in serum protects IGFI from proteolytic degradation and prolongs its half-life $(10$, 12). In some systems, IGFBPs inhibit the action of IGF-I (42, $45-47)$ whereas in others they enhance IGF-I's action $(47,48)$ or appear to be bioactive in the absence of IGF-I (49). The IGFBPs secreted by the TC-1 cells are similar in size to those observed in cultures of other cell types. Further studies are necessary to determine their relationship to other IGFBPs and their actions.

Growth hormone and IGF-I play an important role in hematopoiesis. Whereas both growth hormone and IGF-I enhance human marrow erythroid and granulocytic progenitor cell growth in vitro $(20-24,36,37)$, the effect of growth hormone requires the presence of adherent cells and is abrogated by monoclonal antibodies directed against IGF-I membrane receptors $(22,24)$. Although the precise cellular origin of IGF-I is unclear, monocytes from the marrow adherent layer have been implicated as the source of IGF-I, because these cells were required for stimulation of erythropoiesis or granulopoiesis by growth hormone. In these cultures, IGF-I did not appear to induce the production of hematopoietic factors from accessary cells nor did it replace erythropoietin or colony-stimulating activity. However, recent studies, using highly purified colonyforming units erthyroid (CFU-E), demonstrated that physiologic concentrations of IGF-I directly enhanced CFU-E growth and was not dependent on the presence of accessory cells (37). Whereas marrow macrophages may constitute a source of IGFI, the results of the present study clearly demonstrate that marrow stromal cells constitute another potential source of this peptide. IGF-I released by stromal cells may act in concert with other hormones and cytokines such as erythropoietin in the regulation of hematopoiesis. In addition, the release of IGFBP by stromal cells may modulate the effects of IGF-I within the marrow microenvironment. Although the precise biologic role of IGF-I and IGFBP secreted by stromal cells remains to be determined, the TC-1 cells provide a valuable model to study further the regulation of IGF-I and IGFBP production and their interactions.

\section{Acknowledgments}

We thank Ms. Sandra Evans for her expert preparation of the manuscript.

This work was supported by the Medical Research Service of the Department of Veterans Affairs and by National Institutes of Health Grant DK-41527 awarded to DCA.

\section{References}

1. Sara, V. R., and K. Hall. 1990. Insulin-like growth factors and their binding proteins. Physiol. Rev. 70:591-614.

2. Van Wyk, J. J. 1984. The somatomedins: biological actions and physiological control mechanisms. In Hormonal Proteins and Peptides. Vol. XII. C. H. Li, editor. Academic Press, Inc., New York. 82.

3. Han, V. K. M., A. J. D'Ercole, and P. K. Lund. 1987. Cellular localization of somatomedin (insulin-like growth factor) messeriger RNA in the human fetus. Science (Wash. DC). 236:193-197.

4. D'Ercole, A. J., A. D. Stiles, and L. E. Underwood. 1984. Tissue concentrations of somatomedin C: further evidence for multiple sites of synthesis and paracrine or autocrine mechanisms of action. Proc. Natl. Acad. Sci. USA. 81:935-939.

5. Clemmons, D. R., and J. J. Van Wyk. 1985. Evidence for a functional role of endogenously produced somatomedin-like peptides in the regulation of DNA synthesis in cultured human fibroblasts and porcine smooth muscle cells. J. Clin. Invest. 75:1914-1918.

6. Clemmons, D. R., and D. S. Shaw. 1986. Purification and biologic properties of fibroblast somatomedin. J. Biol. Chem. 261:10293-10298.

7. Aron, D. C., J. L. Rosenzweig, and H. E. Abboud. 1989. Synthesis and binding of insulin-like growth factor I by human mesangial cells. J. Clin. Endocrinol. Metab. 68:585-591.

8. Pinzani, M., H. E. Abboud, and D. C. Aron. 1990. Secretion of insulin-like growth factor-I and binding proteins by rat liver fat-storing cells: regulatory role of platelet-derived growth factor. Endocrinology. 127:2343-2349.

9. Underwood, L. E., A. J. D'Ercole, D. R. Clemmons, and J. J. Van Wyk. 1986. Paracrine functions of somatomedins. Clin. Endocrinol. Metab. 15:59-77.

10. Holly, J. M. P., and J. A. H. Wass. 1989. Insulin-like growth factors: autocrine, paracrine or endocrine? New perspectives of the somatomedin hypothesis in the light of recent developments. J. Endocrinol. 122:611-618.

11. Daughaday, W. H., M. Kapadia, and I. Mariz. 1987. Serum somatomedin binding proteins: physiologic significance and interference in radioligand assay. $J$. Lab. Clin. Med. 109:355-363.

12. Ooi, G. T. 1990. Insulin-like growth factor-binding proteins (IGFBPs): more than just 1, 2, 3. Mol. Cell. Endocrinol. 71:C39-C43.

13. Yang, Y. W.-H., A. L. Brown, C. C. Orlowski, D. E. Graham, L. Y.-H. Tseng, J. A. Romanus, and M. M. Rechler. 1990. Identification of rat cell lines that preferentially express insulin-like growth factor binding proteins rIGFBP-1, 2, or 3. Mol. Endocrinol. 4:29-38.

14. Bar, R. S., B. A. Booth, M. Boes, and B. L. Dake. 1989. Insulin-like growth factor-binding proteins from vascular endothelial cells: purification, characterization, and intrinsic biological activities. Endocrinology. 125:1910-1920.

15. Conover, C. A., F. Liu, D. Powell, R. G. Rosenfeld, and R. L. Hintz. 1989. Insulin-like growth factor binding proteins from cultured human fibroblasts. $J$. Clin. Invest. 83:852-859.

16. Clemmons, D. R., K. M. Thrailkill, S. T. Handwerger, and W. H. Busby, Jr. 1990. Three distinct forms of insulin-like growth binding proteins are released by decidual cells in culture. Endocrinology 127:643-650.

17. Baxter, R. C., and J. L. Martin. 1987. Binding proteins for insulin-like growth factors in adult rat serum: comparison with other human and rat binding proteins. Biochem. Biophys. Res. Commun. 147:408-415.

18. Robinson, B. E., and P. J. Quesenberry. 1990. Hematopoietic growth factors: overview and clinical applications. Part I. Am. J. Med. Sci. 300:163-170.

19. Robinson, B. E., and P. J. Quesenberry. 1990. Hematopoietic growth factors: overview and clinical applications. Part II. Am. J. Med. Sci. 300:237-244.

20. Migliaccio, G., A. R. Migliaccio, and J. W. Adamson. 1990. The biology of hematopoietic growth factors: studies in vitro under serum-deprived conditions. Exp. Hematol. (NY). 18:1049-1055.

21. Claustres, M., P. Chatelain, and C. Sultan. 1987. Insulin-like growth factor I stimulates human erythroid colony formation in vitro. J. Clin. Endocrinol. \& Metab. 65:78-82.

22. Merchev, S., S. Tatarsky, and Z. Hochberg. 1988. Enhancement of erythropoiesis in vitro by human growth hormone is mediated by insulin-like growth factor I. Br. J. Haematol. 70:267-271.

23. Sawada, K., S. B. Krantz, E. N. Dessypris, S. T. Koury, and S. T. Sawyer. 1989. Human colony-forming units-erythroid do not require accessory cells, but do require direct interaction with insulin-like growth factor I and/or insulin for erythroid development. J. Clin. Invest. 83:1701-1709. 
24. Merchav, S., I. Tatarsky, and Z. Hochberg. 1988. Enhancement of human granulopoiesis in vitro by insulin-like growth factor I/somatomedin C and human growth hormone. J. Clin. Invest. 81:791-797.

25. Rom, W. N., P. Basset, G. A. Fells, T. Nukiwa, B. C. Trapnell, and R. G. Crystal. 1988. Alveolar macrophages release an insulin-like growth factor I-type molecule. J. Clin. Invest. 82:1685-1693.

26. Geffner, M. E., N. Bersch, B. M. Lippe, R. G. Rosenfeld, R. L. Hintz, and D. W. Golde. 1990. Growth hormone mediates the growth of T-lymphoblast cell lines via locally generated insulin-like growth factor I. J. Clin. Endocrinol. \& Metab. 71:464-469.

26. Quesenberry, P. J., I. K. McNiece, B. E. Robinson, T. A. Woodward, G. B Baber, H. E. McGrath, and P. C. Isakson. 1987. Stromal cell regulation of lymphoid and myeloid differentiation. Blood Cells. 13:137-146.

27. Gimble, J. M. 1990. The function of adipocytes in the bone marrow stroma. The New Biologist. 2:304-312.

28. Song, Z. X., R. K. Shadduck, D. J. Innes, Jr., A. Waheed, and P. J. Quesenberry. 1985. Hematopoietic factor production by a cell line (TC-1) derived from adherent murine marrow cells. Blood. 66:273-2281.

29. Song, Z. X., C. Thomas, D. Innes, A. Waheed, R. K. Shadduck, and P. J. Quesenberry. 1988. Characterization of two clones isolated from the TC-1 murine marrow stromal cell line: growth factor and retrovirus production and physical support of hemopoiesis. Int. J. Cell. Cloning. 6:125-145.

30. Sambrook, J., E. F. Fritsch, and T. Maniatis. 1989. Molecular Cloning: A Laboratory Manual. Cold Spring Harbor Laboratory Press, Cold Spring Harbor, NY.

31. Ausubel, F. M., R. Brent, R. E. Kingston, D. D. Moore, J. G. Seidman, J. A. Smith, and K. Struhl. 1990. Current Protocols in Molecular Biology. John Wiley \& Sons, New York.

32. Bortz, J. D., P. Rotwein, D. DeVol, P. J. Bechtel, V. A. Hansen, and M. R. Hammerman. 1988. Focal expression of insulin-like growth factor I in rat kidney collecting duct. J. Cell Biol. 107:811-819.

33. Silver, B. J., F. E. Jaffer, and H. E. Abboud. 1989. Platelet-derived growth factor synthesis in mesangial cells: induction by multiple peptide mitogens. Proc. Natl. Acad. Sci. USA. 86:1056-1060.

34. Martin, J. L., and R. C. Baxter. 1986. Insulin-like growth factor-binding protein from human plasma. J. Biol. Chem. 261:8754-8760.

35. Hossenlopp, P., D. Seurin, B. Segovia-Quinson, S. Hardovin, and M. Binoux. 1986. Analysis of serum insulin-like growth factor binding proteins using Western blotting: use of the method for titration of the binding proteins and competitive binding studies. Anal. Biochem. 154:138-143.

36. Kurtz, A., W. Hartl, W. Jelkman, J. Zapf, and C. Bauer. 1985. Activity in bovine serum that stimulates erythroid colony formation in fetal mouse livers is insulin-like growth factor. $J$. Clin. Invest. 76:1643-1648.

37. Akahane, K., A. Tojo, A. Urabe, and F. Takaku. 1987. Pure erythropoi- etic colony and burst formations in serum-free culture and their enhancement by insulin-like growth factor I. Exp. Hematol. (NY). 15:797-802.

38. Yee, D., S. Paik, G. S. Lebovic, R. R. Marcus, R. E. Favoni, K. J. Cullen, M. E. Lippman, and N. Rosen. 1989. Analysis of insulin-like growth factor I gene expression in malignancy: evidence for a paracrine role in human breast cancer. Mol. Endocrinol. 3:509-517.

39. Rotwein, P. 1986. Two insulin-like growth factor messenger RNAs are expressed in human liver. Proc. Natl. Acad. Sci. USA. 83:77-81.

40. Smith, E. P., M. E. Svoboda, J. J. Van Wyk, A. L. Kierszenbaum, and L. L. Tres. 1987. Partial characterization of a somatomedin-like peptide from the medium of cultured rat Sertoli cells. Endocrinology. 120:186-192.

41. Clemmons, D. R., R. G. Elgin, V. K. M. Han, S. J. Casella, A. J. D'Ercole, and J. J. Van Wyk. 1986. Culture fibroblast monolayers secrete a protein that alters the cellular binding of somatomedin-C/insulinlike growth factor I. J. Clin. Invest. 77:1548-1553.

42. DeVroede, M. A., L. Y.-H. Tseng, P. G. Katsoyannis, S. P. Nissley, and M. M. Rechler. 1986. Modulation of insulinlike growth factor I binding to human fibroblast monolayer cultures by insulinlike growth factor carrier proteins released to the incubation media. J. Clin. Invest. 77:602-613.

43. Roghani, M., P. Hossenloop, P. Lepage, A. Balland, and M. Binoux 1989. Isolation from human cerebrospinal fluid of a new insulin-like growth factorbinding protein with a selective affinity for IGF-II. FEBS (Fed. Eur. Biochem. Soc.) Lett. 255:253-258.

44. Shimasaki, S., F. Uchiyama, M. Shimonaka, and N. Ling. 1990. Molecular cloning of the cDNAs encoding a novel insulin-like growth factor-binding protein from rat and human. Mol. Endocrinol. 4:1451-1458.

45. Elgin, R. G., W. H. Busby, Jr., and D. R. Clemmons. 1987. An insulin-like growth factor (IGF) binding protein enhances the biologic response to the IGF-I. Proc. Natl. Acad. Sci. USA. 84:3254-3258.

46. Mohan, S., C. M. Bautista, J. Wergedal, and D. J. Baylink, 1989. Isolation of an inhibitory insulin-like growth factor (IGF) binding protein from bone cellconditioned medium: a potential local regulator of IGF action. Proc. Natl. Acad. Sci. USA. 86:8338-8342.

47. Demellow, J. S. M., and R. C. Baxter. 1988. Growth hormone-dependent insulin-like growth factor (IGF) binding protein both inhibits and potentiates IGF-I-stimulated DNA synthesis in human skin fibroblasts. Biochem. Biophys. Res. Commun. 156:199-204.

48. Ernst, M., and G. A. Rodan. 1990. Increased activity of insulin-like growth factor (IGF) in osteoblastic cells in the presence of growth hormone (GH): positive correlation with the presence of the GH-induced IGF-binding protein BP-3. Endocrinology. 127:807-814.

49. Blum, W. F., E. W. Jenne, F. Reppin, K. Kietzmann, M. B. Ranke, and J. R. Bierich. 1989. Insulin-like growth factor I (IGF-I)-binding protein complex is a better mitogen than free IGF-I. Endocrinology. 125:766-772. 